excellences of the clinic has been its readiness to expound its technical methods and the results obtained by them to visitors of any nationality. There is no doubt that the inception und later the guidance of this great experiment in group practice were controlled by Dr. Mayo ; and the success which has attended his aims stamps him as a man of singular vision, broad outlook, indomitable perseverance, possessed of administrative powers of the highest order.

In the practice of his craft, Dr. Mayo was in the first rank. His personality and sincerity at once gained and ever afterwards retained the confidence of his patients; as an operator he could bo cautious or bold as the occasion demanded, and with his enormous experience and thought for individual patients those who worked with him came to rely implicitly on his surgical judgment. His chief interests lay in the surgery of the alimentary and biliary tracts, and to these he made many substantial contributions. Ho was sedulous in promoting the advancement of surgery in the United States, and to this end interested himself actively in the founding and governing of the American College of Surgeons and the f-merican Surgical Association. This disinterested devotion to surgery was honoured by learned bodies all over the world.

As must men whose energies are devoted to the control of great enterprises, he kept himself somewhat apart. But he was a warmhearted and generous helper of his juniors, for he knew better than most, and lived to see himself right, that to justify his conceptions the organization which ho built almost with his own hands must live on after ho relinquished activo control.

J. R. LearMoNth.

\section{Prof. R. W. Reid}

Prof. Robert IV. Reid, emeritus regius pro. fessor of anatomy in the University of Aberdeen, the Nestor among British anatomists, died in Aberdeen on July 28, aged eighty-eight years. He was born in the manse of Auchindoir, Aberdeenshire, in 1851, and after graduating in medicino in the University of Aberdeen, became demonstrator of anatomy in St. 'Thomas's Hospital, London, in 1873, being almost the first medical man to be attached to a London hospital as anatomist. In 1889, he succeeded Sir John Struthers as professor of anatomy in the University of Aberdeen. He held this chair for thirty-six years, retiring in 1925 .

Reid was the sole survivor of the anatomists who founded the Anntomical Society in 1887; he became president of the Society in 1910. Ho was elected a fellow of the Royal Anthropological Institute in $\mathbf{1 8 8 6 .}$ ITis first important contribution to anatomy was entitled "Observations on the Relution of the Principal Fissures and Convolutions of the Cerebrum to the Outer Surface of the Scalp"; this appeared in the Lancet of September 27, 1884, and it contains a description of a base line-spoken of to-day as "Reid's I3ase Line". Two other important papers on topographical anatomy wero published by him in the Journal of Anatomy-one on the relationship of nerve roots to vertebral markings; the other on the position of the chief nerve trunks.

Soon after being appointed to Aberdeen, he estab. lished in connexion with his department an anthropo: Iogical bureau to register the physical characters of the students who entered and to keep a record of their growth changes. Reports from the valuable data thus collected have appeared in the Journal of the Royal Anthropological Institute. IRecords aro still being kept, and no doubt will provide the material for further papers dealing with the anthropology of the Scottish student. Another great service he rendered to the prehistory of Scotland by the preservation and study of the remains of the strange peoplo who first appeared in Aberdeenshire early in the second millennium B.c. His own physical features were so similar to theirs that one had reason to regard him as a deacendant of these early Bronzo Ago settlers in tho north-east part of Scotland. Tho Anthropological Museum of the University of Aberdeen, in which theso unique specimens are preserved, owes more to Prof. Reid than the "Illustrated Cata. logue of Specimens from Prehistoric Interments found in the North East of Scotland" which he wrote in 1924. In acknowledgment of what he did for thi Museum and for the University, his friends and pupils endowed a lectureship in connexion with it-known as the Reid Lectureship. He was the moving spirit and the purse-bearer-that brought into existence the Anatomical and Anthropological Society of the University of Aberdeen. In person he was retiring, almost morbidly modest, charitable and very hospitable.

\section{Dr. W. A. Potts}

I. R. William Alexander FotTs, who died on July 23 in Birmingham at the age of seventy-three years, was a familiar figure to thoso interested in psychological medicine and latterly also to those interested in criminology.

Potts started his scientific career at the East Riding Mental Hospital, Beverloy, but left this branch of work to go into general practice, where he remained for fully twenty years. After this he became medical adviser to the Birmingham Mental Deficiency Com. mitteo and so his more scientific side becamo concentrated on the mentally defective. Since 1919 he had been very helpful in an advisory capacity to the police courts in Birmingham, particularly when they were dealing with cases of mental deficiency. He was also medical adviser to the Barr Park Colony and consultant to the Royal Albert Institution. He was chairman of the Special Schools After-Care Com. mitteo in Birminghum. Ho carried out a considerablo amount of work lecturing and teaching, and colluborated with Shuttleworth in his "Mentally Deficient Children".

He was a most charming personality and always had a ready smile and a helping hand for the young men.

WE regret to announce the death of Mr. H. P. Hollis, a former president of the British Astronomical Association, on August 7 , aged eighty-ono years. 